Sympozjum

Rok XXV 2021, nr 1(40), s. 83-102

\title{
Renata Borowiecka
}

Akademia Muzyczna im. Krzysztofa Pendereckiego w Krakowie ORCID: 0000-0003-4325-8944; e-mail: renata.borowiecka@amuz.krakow.pl https://doi.org/10.4467/25443283SYM.21.007.13720

\section{SEKWENCJA STABAT MATER \\ WE WŁOSKICH INTERPRETACJACH MUZYCZNYCH DOBY XVIII WIEKU}

THE STABAT MATER

SEQUENCE IN ITALIAN MUSICAL INTERPRETATIONS

OF THE 18TH-CENTURY

\begin{abstract}
Abstrakt
Treść poematu Stabat Mater, opisującego postać Matki Bożej cierpiącej pod krzyżem, na którym umiera Jezus - Jej Syn, stała się jednym z uniwersalnych tematów sztuki, zainspirowała kompozytorów różnych wieków i ośrodków, co znalazło swój wyraz w bardzo licznych interpretacjach muzycznych. Spośród ponad 4000 kompozycji do tekstu sekwencji znaczna część to dzieła XVIII-wieczne (najczęściej późnobarokowe), pochodzące z kręgu włoskiego. Chcąc zinterpretować utwór słowno-muzyczny XVIII wieku, nie sposób czynić tego w oderwaniu od teorii afektów i retoryki muzycznej, które uzależniają tekst od muzyki zarówno na poziomie emotywnym, jak i symbolicznym.
\end{abstract}


Referat stanowi próbę oglądu kompozycji Stabat Mater w kontekście retoryki na trzech odpowiadających jej poziomach: inventio, dispositio i decoratio. Wyartykułowane są tendencje wspólne oraz indywidualne, przejawiające się w odpowiednim doborze tonacji, tempa i figur retorycznych, a także pewnych motywów melodycznych, rytmicznych lub struktur harmonicznych funkcjonujących w roli znaku ilustracyjno-symbolicznego. Zaprezentowane zostają punkty węzłowe dzieł oraz prośby człowieka skierowane do Matki (druga część sekwencji) o różnorakiej intonacji błagalnej. Wskazana jest funkcja i przesłanie kompozycji.

W czasach współczesnych Stabat Mater wielkich twórców rozbrzmiewają głównie jako dzieła koncertowe we wnętrzach kościelnych lub świeckich. Żywotność tych interpretacji 300 lat od ich powstania świadczy niewątpliwie o kompozytorskim kunszcie utworów oraz o ich znaczeniu nie tylko dla muzyki XVIII wieku, ale i dla dzisiejszej kultury i wiary.

Słowa kluczowe: muzyka włoska, muzyka religijna, sekwencja Stabat Mater, XVIII wiek

\section{Abstract}

The Stabat Mater poem, which describes the suffering of Blessed Virgin Mary under the cross on which Jesus - her Son - is dying, has become a universal theme which inspired composers of various ages and origins and found its expression in numerous musical interpretations. From among over 400 compositions which set the text of the sequence to music, a large proportion are $18^{\text {th }}$-century works (mostly - late baroque) of Italian provenience. Attempting to interpret a musical composition with text of the $18^{\text {th }}$ century, one has to take into account the theory of affects and musical rhetoric, which make the text dependent on music both on the emotive and symbolic level.

The paper will examine the Stabat Mater compositions in the rhetoric context, referring to three main levels: inventio, dispositio and decoratio. The common and individual tendencies will be articulated, evident by the appropriate choice of the key, tempo and rhetorical figures, as well as by some melodic and rhythmic motives or harmonic structure having function of the special illustrative-symbolic signs. The nodal points of the work will 
be presented as well as the requests of man directed at the Mother (the second part of the sequence) assuming varying intonations of supplication. The function and the message of the compositions are advisable.

In contemporary times Stabat Mater of the great composers resound mainly as concert masterpieces in church and secular interiors. The vitality of these interpretations after three hundred years from their creation most certainly bears witness to the composers' artistry in their works and proves their significance not only for the music of the $18^{\text {th }}$ century but also for the culture and faith of today.

Keywords: Italian music, religious music, the Stabat Mater sequence, $18^{\text {th }}$-century

\section{Exordium}

Wydarzenia opisane na kartach Ewangelii i sformułowane w prawdach wiary inspirują sztukę chrześcijańską od jej zarania, pojawiając się jako tematy dzieł literackich, plastycznych i muzycznych. Na tę sferę inspiracji zwracał uwagę św. Jan Paweł II, pisząc w Liście do artystów o religii jako swoistej „ojczyźnie duszy”, która może być wielkim źródłem natchnienia. Kontynuując rozważania, papież dodawał: „(...) temat religijny należy do najczęściej podejmowanych [przez twórców] każdej epoki. (...) przyczyniło się to do lepszego zrozumienia człowieka, jego autentycznego oblicza, jego prawdy. Ujawniła się także szczególna więź między sztuką a chrześcijańskim objawieniem"1.

Przez stulecia sztuka w sposób szczególny pomagała człowiekowi przybliżać się i próbować zrozumieć największą tajemnicę chrześcijaństwa - tajemnicę odkupienia. Z odkupieńczym cierpieniem Jezusa złączona pozostaje Jego Matka, która utrzymała wiernie swoje zjednoczenie z Synem aż do Krzyża, stając się dla Kościoła wzorem wiary i miłości.

Ksiądz Bogusław Nadolski zwraca uwagę, iż pasyjny nurt pobożności maryjnej - rozwijający się w Kościele od czasów średniowiecza -

${ }^{1}$ Jan Pawe€ II, List do artystów, Rzym 1999, 13. 
wyraził się w „tworzeniu osobnego gatunku pieśni pasyjnej zwanej planktem (...), a upowszechnianie się tego gatunku łączyło się w wiekach średnich z niebywałym wprost rozwojem mariologii" ${ }^{2}$. Do omawianego typu dzieł zaliczyć należy poemat Stabat Mater dolorosa. Tekst ten wrósł jako sekwencja i hymn w liturgię Kościoła. Na przestrzeni wieków doczekał się imitacji, parafraz, tekstów pokrewnych. Wyraziście wpisał się także w świat sztuki muzycznej. Poprzez interpretację dźwiękową słów planktu kompozytorzy przekazywali nie tylko wyznanie wiary chrześcijańskiej, ale i przeżycia osobiste, indywidualne.

Spośród bogatego repertuaru opracowań poematu (ponad 400 kompozycji ${ }^{3}$ ) znaczna część to dzieła XVIII-wieczne, pochodzące z kręgu włoskiego. Do grupy ważkich Stabat Mater doby Settecenta z pewnością należą interpretacje Emanuela d'Astorgi (1680-1757), Antonia Vivaldiego (1678-1741), Domenica Scarlattiego (1685-1757), Alessandra Scarlattiego (1660-1725), Antonia Caldary (ok. 1670-1736), Antonia Marii Bononciniego (1677-1726), Agostina Steffaniego (1654-1728), Giovanniego Battisty Pergolesiego (1710-1736), Tommasa Traetty (1727-1779) i Luigiego Boccheriniego (1743-1805). Wszystkie wymienione kompozycje późnego baroku i wczesnego klasycyzmu zapisały się jako znaczące dokonania w historii wielogłosowych umuzycznień poematu, lecz przypomnieć należy, iż wyjątkową rolę w rozwoju stylu muzycznego XVIII wieku odegrało Stabat Mater Giovanniego Battisty Pergolesiego, które osiągnęło niezwykłą sławę w całej Europie zaledwie kilka lat po śmierci twórcy i nieprzerwanie do czasów obecnych cieszy się opinią dzieła wybitnego.

\section{Stabat Mater - geneza tekstu}

Źródeł tekstu Stabat Mater poszukiwać należy przede wszystkim w Piśmie Świętym. W Nowym Testamencie szczególną uwagę postaci Maryi

2 B. Nadolski, Liturgika, t. 2: Liturgia i czas, Poznań 2013, s. 254.

3 Zob. J. Blume, Geschichte der mehrstimmigen Stabat-mater-Vertonungen, München-Salzburg 1992. 
poświęcają św. Łukasz oraz św. Jan i to właśnie w relacjach owych dwóch ewangelistów (por. J 19,25-26; Łk 2,34-35) odnaleźć można słowa, które znajdują swój rezonans w poemacie. Przytoczone wersy Pisma Świętego objawiają, że Maryja będzie cierpieć u boku umierającego Zbawiciela, a trwając wiernie przy Krzyżu Syna, stanie się Matką wszystkich ludzi i członkiem eschatycznej rodziny Jezusa.

Ponadto korzenie Stabat Mater sięgają przedstawień pasyjnych, w których punkt kulminacyjny stanowiły lamentacje maryjne. Związane są także z propagowaną przez zakon franciszkanów medytacją cierpienia Chrystusa i boleści Matki na Golgocie. Przyczyn stworzenia poematu oraz późniejszej jego popularności na całym kontynencie upatrywać należy również w mistyczno-pokutnej żarliwości, która przeniknęła zachodnią Europę w późnym średniowieczu. Wędrujący w procesjach biczownicy wykonywali hymny gloryfikujące cierpienia Chrystusa i Jego Matki; z biegiem czasu do tekstów szczególnie faworyzowanych należał poemat Stabat Mater ${ }^{4}$.

Nie wiadomo, kiedy dokładnie powstał ów tekst, nieznany pozostaje również jego autor, choć wnikliwie prowadzone badania wskazują na późny wiek XIII oraz krąg franciszkański, w którym najczęściej wymienianym twórcą jest Jacopone da Todi (ok. 1230-1306).

4 A. T. Sharp, A Descriptive Catalog of Selected, Published Eighteenth-through Twentieth-Century Stabat Mater Settings for Mixed Voices with a Discussion of the History of the Text, Ph.D. Thesis, University of Iowa 1978, s. 17. Por. K.-H. Schlagen, M. MarX-Weber, Stabat Mater, w: L. Finscher (hrsg. von), Die Musik in Geschichte und Gegenwart, Sachteil, t. 8, Kassel-Stuttgart 1998, s. 1708-1721; H. T. Henry, P.-D. Masiclat, Stabat Mater dolorosa, w: The Catholic Encyclopedia, Online Edition 2003, https://www.newadvent.org/ cathen/ (odczyt z dn. 15.04.2021 r.); J. Mearns, Stabat Mater, w: J. Julian (red.), A Dictionary of Hymnology, London 1907, s. 1082. 


\begin{tabular}{|l|l|}
\hline \multicolumn{2}{|c|}{ Stabat Mater - historia i funkcja tekstu } \\
\hline $\begin{array}{l}\text { PIERWOTNA FUNKCJA } \\
\text { POEMATU }\end{array}$ & $\begin{array}{l}\text { Modlitwa rymowana, przeznaczona } \\
\text { do prywatnego nabożeństwa }\end{array}$ \\
\hline $\begin{array}{l}\text { PRZELOM XIII i XIV } \\
\text { WIEKU }\end{array}$ & $\begin{array}{l}\text { Poemat zawierają księgi liturgiczne, ale } \\
\text { wyłącznie w formie ręcznych dopisków }\end{array}$ \\
\hline WCZESNY WIEK XIV & Tekst występuje w modlitewnikach \\
\hline XV WIEK & $\begin{array}{l}\text { Stabat Mater zostaje wpisane jako } \\
\text { sekwencja w różnorakich mszałach } \\
\text { (z wyjątkiem angielskich) }\end{array}$ \\
\hline KONIEC XV WIEKU & $\begin{array}{l}\text { Sekwencja Stabat Mater zostaje } \\
\text { włączona do liturgii łacińskiej }\end{array}$ \\
\hline $\begin{array}{l}\text { XVI WIEK } \\
\text { - SOBÓR TRYDENCKI }\end{array}$ & $\begin{array}{l}\text { Wyłączono sekwencję Stabat Mater } \\
\text { z liturgii łacińskiej }\end{array}$ \\
\hline 1727 ROK & $\begin{array}{l}\text { W związku z ustanowieniem przez } \\
\text { papieża Benedykta XIII święta } \\
\text { Siedmiu Boleści Świętej Panny Maryi } \\
\text { Stabat Mater wchodzi ponownie } \\
\text { do kanonu liturgicznego w funkcji } \\
\text { sekwencji i hymnu (feria VI post } \\
\text { Dominicam Passionis) }\end{array}$ \\
\hline $\begin{array}{l}\text { REFORMA LITURGICZNA } \\
\text { WATYKAŃSKIEGO }\end{array}$ & $\begin{array}{l}\text { Stabat Mater pozostaje wyłącznie w roli } \\
\text { hymnu brewiarzowego. Jako sekwencja } \\
\text { może być wykonywane ad libitum } \\
\text { w całości lub od słów 11. strofy (Santa } \\
\text { Mater istud agas) }\end{array}$ \\
\hline
\end{tabular}

W długiej historii funkcjonowania Stabat Mater ważną datą wydaje się 1727 rok, kiedy to - jak pisze Paul-Gerhard Nohl - liturgia wyszła naprzeciw ogromnej popularności tekstu 5 . O wielkim powodzeniu Stabat

\footnotetext{
5 Por. P.-G. NohL, Das „Stabat Mater”, „Musik und Kirche” 67 (1997), s. 97.
} 
Mater świadczyć mogą również zachowane do dziś w licznych źródłach różne wersje melodii chorałowych i różne warianty słowne poematu, jego uzupełnienia, przekształcenia, w końcu imitacje (z najbardziej znaną - Stabat Mater speciosa) ${ }^{6}$. Co ciekawe, także w liturgii polskich Gorzkich żalów pobrzmiewają frazy sekwencji (teksty ułożone w 1707 roku).

\section{Stabat Mater - interpretacje słowno-muzyczne}

Jak pisał Nicolaus Harnoncourt - znamienity dyrygent i interpretator muzyki dawnej - „muzyka barokowa zawsze chciała coś wyrażać, choćby jakieś ogólne uczucie, bądź wywołać jakiś określony afekt. No i w końcu «mowa dźwięków», która począwszy od ok. 1650 roku przez prawie dwa stulecia odgrywała w muzyce rolę fundamentalną"7. Próbując odczytać znaczenia i sensy niesione przez dzieło muzyczne doby XVIII wieku, należy pamiętać o podstawowym dla tego czasu celu muzyki - przedstawianiu i wywoływaniu emocji. Stąd też niezbędnymi stają się odwołania do koncepcji teorii afektów - „siły napędowej” nowego myślenia o muzyce i nowego sposobu komponowania łączącego się z racjonalną umiejętnością wywoływania emocji, czemu służyć miała retoryka muzyczna. W myśl ówczesnych zasad utwór postrzegany był jako oracja muzyczna. Poszukiwanie tematu oracji, już na etapie wstępnym - inventio, wiązało się z poszukiwaniem odpowiednich afektów. Polski muzykolog Jarosław Mianowski przypominał, że użycie topoi religijnych z góry zakłada dominację takich afektów, jak miłosierdzie, ufność, wiara, nadzieja, cierpienie, przy mniejszym udziale czy wręcz nieobecności innych ${ }^{8}$.

Afektami dominującymi w tekście Stabat Mater są cierpienie, ale i compassio - współodczuwanie bólu, świadome współczucie w wewnętrznej zgodzie z Chrystusowym zamiarem dokonania zbawienia. Należy

${ }^{6}$ Por. A. T. Sharp, A Descriptive Catalog..., dz. cyt.; D. Faravelli, Stabat Mater: poesia e musica, „Rivista Internazionale di Musica Sacra” 1 (1983), s. 9-43; J. CaldwelL, M. Boyd, Stabat Mater dolorosa, w: S. Sadie, J. Tyrrell (red.), The New Grove Dictionary of Music and Musicians, second ed., t. 24, London 2001, s. 234-236.

${ }^{7}$ N. Harnoncourt, Muzyka mową dźwięków, tłum. M. Czajka, Warszawa 1995, s. 148.

${ }^{8}$ Por. J. Mianowski, Afekt w operach Mozarta i Rossiniego, Poznań 2004, s. 51. 
także przypomnieć, że w długim tekście poematu wydzielić można kilka spójnych części, choć najbardziej wyraziście rysują się dwie.

Pierwsza z nich - lamentacyjna (strofy 1-8) - wprowadza i obrazuje sytuację (bezpośrednie odwołania do Biblii: bolejąca Matka pod Krzyżem, miecz przeszywający Jej duszę), przywołuje intensywne obrazy cierpienia Maryi, których - jak stwierdza Urszula Szwarc - „nikt chętnie nie kontempluje, a których «wytrzymanie» zawsze było stałym elementem nabożeństwa pasyjnego", ${ }^{\prime}$ w końcu - stanowi wyraz ludzkich przeżyć Maryi jako osoby Boskiej (takie postrzeganie, niezwykle nowatorskie, rozpowszechniło się w kołach franciszkańskich). Cierpiąca Maryja symbolizuje bowiem każdą pogrążoną w żałobie matkę. Jak podkreśla Urszula Szwarc: „Patrząc na zmasakrowane i nadal torturowane ciało swojego dziecka, bez wątpienia boleśnie przeżywała wszystko, co się z nim działo (...). A ponieważ jego doznania, jawiące się jako źródło Jej boleści, przynależą do ziemskiej rzeczywistości, również owa boleść Matki musi być podobnie, czy wręcz identycznie postrzegana" ${ }^{\prime 10}$.

Istotnymi dla wymowy sekwencji są także dwa pytania retoryczne postawione w strofach 5. i 6., które - zdaniem muzykologa Wiesława Liseckiego - „apelują do emocji, choć - pozornie - posiadają wartość logiczną"11. Ich kontynuację stanowią strofy mówiące o ofierze Chrystusa za grzech ludzki (Pro peccatis suae gentis) oraz o Jego męce zakończonej śmiercią (koniec 8. strofy - dum emisit spiritum).

Część druga ma charakter błagalny (strofy 9-20), a modlitwa człowieka kierowana do Matki - Źródła Miłości, Świętej, Dziewicy z Dziewic przesławnej - nabiera tonu niemal ekstatycznego. Istotną wymową uporządkowanego gradacyjnie fragmentu błagalnego Stabat Mater jest wskazanie, iż cierpienie Chrystusa i Maryi skłania wiernych do miłości (10. strofa), a męka i śmierć Jezusa stają się wydarzeniami zbawiennymi

9 U. Szwarc, „Twoją duszę miecz przeniknie” (Łk 2,35). Cierpienie Maryi w świetle starotestamentowego przepowiadania, „Salvatoris Mater” 3 (2001), s. 18.

10 Tamże.

11 W. LISECKI, „Stabat Mater” Karola Szymanowskiego jako muzyczna interpretacja przesłania sekwencji, „Zeszyty Naukowe” [Akademia Muzyczna im. F. Nowowiejskiego w Bydgoszczy] 5 (1993), s. 114. 
(koniec sekwencji). W części drugiej obok affectus doloris można wyłonić afekty pozytywne - ufność, wiarę, nadzieję i miłość, a także negatywne - strach i trwogę przed sądem ostatecznym. Wymienione typy emocjonalne znajdują swój wyraz muzyczny na poziomie tak dispositio (tj. rodzaju budowy utworu, jego tonacji, obsady, tempa), jak i decoratio (określonych figur retoryczno-muzycznych). Warto dodać, że w myśl założeń retoryki muzyka „dopisuje” zazwyczaj paralelną do tekstu „treść”, która wzmacnia i dodatkowo eksplikuje warstwę słowną.

Analizując XVIII-wieczne umuzycznienia Stabat Mater z pewnością należy także uwzględnić okoliczności powstania dzieła, bowiem to one determinowały niejednokrotnie jego funkcję, obsadę, gatunek i styl.

Omawiane utwory przeznaczone były często do użytku liturgicznego, na co wyraziście wskazują zamówienia kompozycji Antonia Vivaldiego oraz Alessandra Scarlattiego i Giovanniego Battisty Pergolesiego. Można przypuszczać, iż także Stabat Mater Domenica Scarlattiego funkcjonowało jako dzieło liturgiczne, gdyż kompozytor napisał je w okresie swej działalności w Watykanie, a obsada utworu odpowiada składowi Cappella Giulia. Umuzycznienie Antonia Caldary z obsadą rozbudowaną o puzony, stosowane w wiedeńskiej muzyce religijnej, należało do grupy Stabat Mater solemne, które to kapela cesarska wykonywała w każdą sobotę Wielkiego Postu. Z kolei zwiastunem koncertowej muzyki sakralnej (popularnej od połowy XVIII wieku zwłaszcza w krajach zaalpejskich) wydaje się Stabat Mater Agostina Steffaniego, napisane dla instytucji świeckiej, promującej wykonania pozakościelne. Przypuszczalnie podobnie rzecz przedstawia się w przypadku dzieł Luigiego Boccheriniego i Antonia Ferradiniego.

Niezależnie od rodzaju dzieła, kompozytorzy wykazywali wrażliwość na najbardziej znaczące wątki treściowe poematu Stabat Mater. W ramach formy kilkufazowej lub kilkuczęściowej tworzyli większe całości tematyczno-ekspresyjne, podkreślali punkty węzłowe tekstu słownego, a także kreowali określone tony błagalne.

Exordium (otwarcie) stanowiło zazwyczaj zarysowanie sytuacji dramatycznej i wprowadzenie w dominujący afekt utworu. Wysoce indywidualny rys zyskało w interpretacjach Antonia Vivaldiego i Giovanniego 


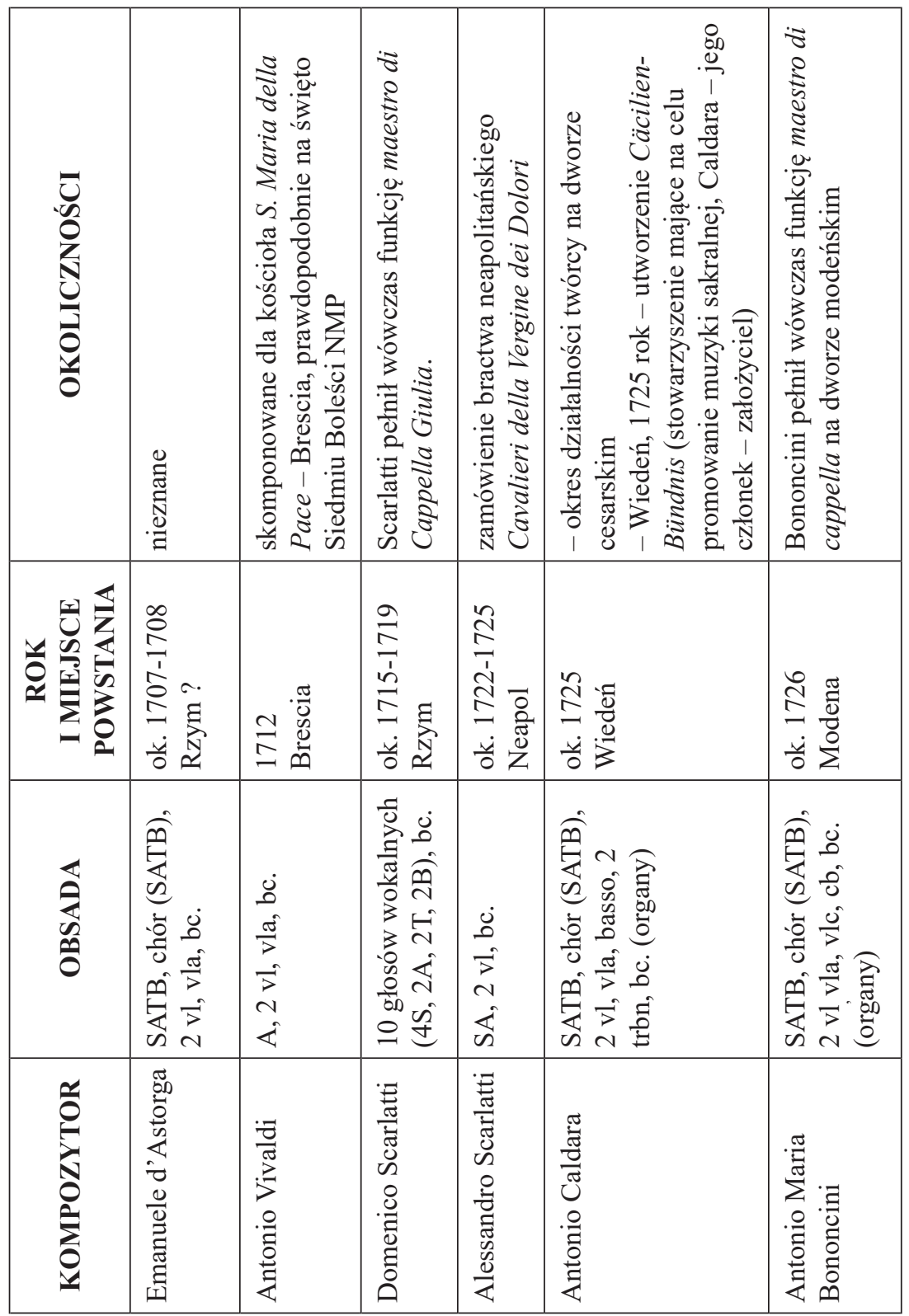




\begin{tabular}{|c|c|c|c|c|c|}
\hline 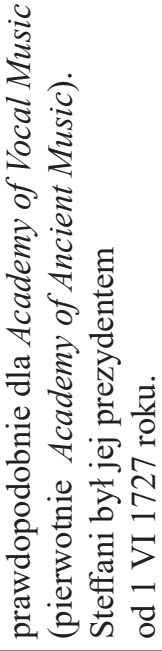 & 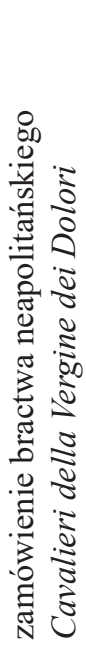 & $\begin{array}{l}\stackrel{\mathscr{J}}{\Xi} \\
\stackrel{\mathbb{J}}{\Xi} \\
\Xi\end{array}$ & 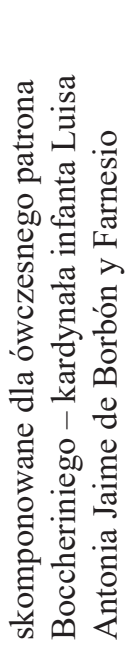 & 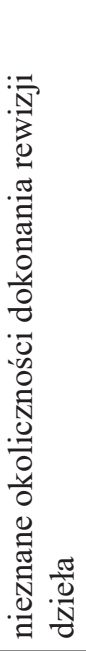 & 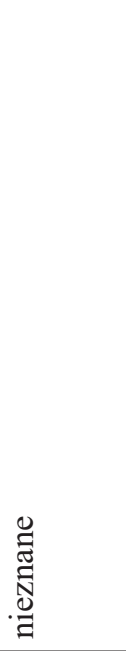 \\
\hline 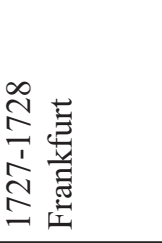 & 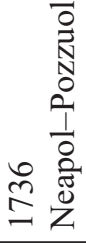 & 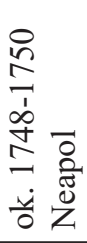 & 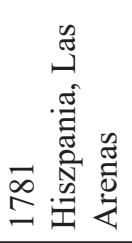 & 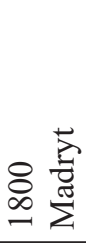 & 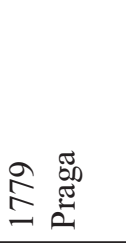 \\
\hline 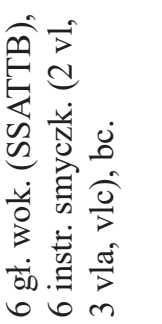 & 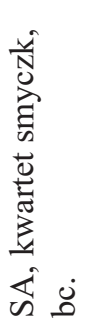 & 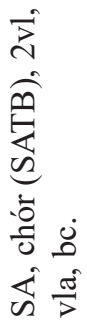 & 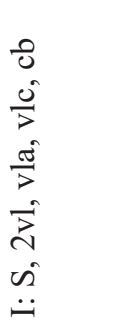 & 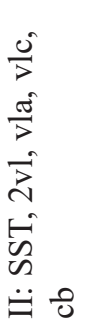 & 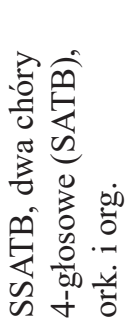 \\
\hline 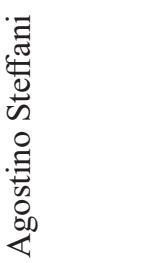 & 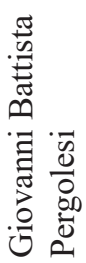 & 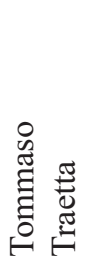 & 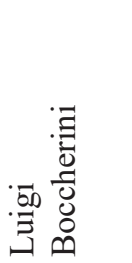 & & 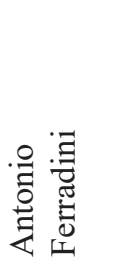 \\
\hline
\end{tabular}


Battisty Pergolesiego. Pierwszy z wymienionych twórców, celem przywołania obrazu Matki Bolejącej na Golgocie, zastosował w przebiegu melodycznym szczególny znak muzyczny - motyw krzyża (specyficzny układ dźwięków tworzy dwie krzyżujące się linie). Jak zauważa Tomasz Jasiński, „jeśli przyjrzeć się wielogłosowym opracowaniom słów: «ukrzyżowany» w Credo i «ukrzyżuj» w twórczości pasyjnej, uderza fakt, iż słowa te bardzo często wyposażone są w taką właśnie strukturę melodyczną, która kryje w sobie wyimaginowany krzyż. Zjawisko występuje w muzyce późnego renesansu (ostatnie dekady XVI w.) i na przestrzeni całej epoki baroku" ${ }^{12}$. Już od II połowy XVI wieku zarówno w kręgach katolickich, jak i protestanckich nasilił się kult Chrystusa Ukrzyżowanego, a owo zwrócenie się ku Ukrzyżowanemu najpełniej konkretyzowało się w rozważaniu i przeżywaniu męki Pańskiej. Integralną część rozważań stanowiło wyobrażenie wizerunku krzyża. Podejście wizualne zetknęło się z barokową zasadą mimesis, która znalazła swoje urzeczywistnienie w figurach retorycznych z grupy hypotyposis. W ową grupę Tomasz Jasiński wpisuje figurę imaginatio crucis. Antonio Vivaldi łączy motyw krzyża z odległymi skokami dysonansowymi (tzw. saltus duriusculus), wzmacniając także warstwę ekspresywną tekstu słownego.

Z kolei Giovanni Battista Pergolesi wprowadza w exordium w wolnym tempie „bolesne” współbrzmienia dysonansowe w układach dwugłosowych. Ten sam kompozytor wyraziście wyróżnia także treści związane z zapowiedzią Symeona (druga strofa sekwencji). Czyni to poprzez struktury rytmiczne, tj. ugrupowania jambiczne (krótka - długa) pozostające w niezgodzie z rytmiką tekstu słownego (trochej: długa - krótka). Tym samym zarówno wizualizuje ów obraz „miecza przenikającego duszę Bożej Rodzicielki”, jak i wyraża dominujący afekt boleści. Z perspektywy minionych stuleci kuriozalną jawi się opinia o niewłaściwym podłożeniu przez Giovanniego Battistę Pergolesiego rytmu muzycznego w stosunku do tekstu poetyckiego i poprawianie „błędów kompozytorskich”

12 T. JAsı́́sKI, „Imaginatio crucis” w muzyce baroku, „Zeszyty Naukowe” [Akademia Muzyczna im. I. J. Paderewskiego w Poznaniu] 6 (1994), s. 66. Punktem wyjścia dla rozważań autora jest interpretacja Hermanna Kellera, przypisująca czterodźwiękowej strukturze melodycznej „kształt leżącego krzyża” albo identyfikująca ją jako „rozpięty krzyż”. 
przez teoretyków późnego XVIII wieku ${ }^{13}$, wskazujące na ich niezrozumienie zabiegów retorycznych.

Częstą strategią obecną w Stabat Mater jest wprowadzanie tzw. tercji pikardyjskiej (tj. wielkiej) we współbrzmieniu wieńczącym dzieło. To „rozświetlenie” akordem durowym („radosnym”) przenosi z pewnością w wymiar symboliczny. Poza finałem niektórzy kompozytorzy posługują się tym zabiegiem w zakończeniu części lamentacyjnej sekwencji, w której mowa jest o Krzyżu Zbawiciela i Jego śmierci za grzechy ludzkie. Czyni tak np. Agostino Steffani. Kompozytor stosuje typowe figury retoryczne wzmacniające warstwę semantyczną tekstu (słowa „umieranie”, „wyniszczenie” powiązane z opadaniem melodyki - descensus, kontrastami rejestrów wyżej - niżej, czyli mutatio per systhema). Dodatkowo - nawiązując do muzycznej tradycji pasyjnej - powierza śpiew basowi solo (barwa kojarzona z postacią Jezusa), niekiedy w najniższym z możliwych rejestrów, kontrastując go z tłem jasno brzmiących smyczków (rodzaj aureoli, symbol Boskości Jezusa). Wraz z finałowym „świetlistym” współbrzmieniem kompozytor symbolicznie odwołuje się do tajemnicy zmartwychwstania Jezusa i Jego zwycięstwa nad śmiercią, podkreślając tym samym jedną z głównych prawd wiary.

Prośby człowieka z drugiej części sekwencji, których przedmiotem staje się cierpienie (strofy 9-18) oraz zbawienie (strofy 19-20), w umuzycznieniu kompozytorów XVIII-wiecznych przybierają różnoraką intonację. Należy zaznaczyć, że interpretatorzy Stabat Mater byli przede wszystkim twórcami dzieł operowych, stąd też z tego gatunku przenosili rodzaj kształtowania dramaturgii i sposobu wyrażania emocji na grunt utworu religijnego (odwołanie do zasad: varieta - zróżnicowanie i kontrastowość afektów, chiaroscuro - naprzemienność mniej lub bardziej wyrazistych afektów, intreccio - napięcie pomiędzy afektami). Sprawili tym samym, iż muzyka w części błagalnej niosła obok tonów lamentacyjnych, bolesnych, żałobnych i inne odmienne charaktery emocjonalne - od dramatycznego, żarliwego, triumfalnego przez bardziej zrównoważony do refleksyjnego czy wręcz kontemplacyjnego.

13 Zob. F. K. Grave, Abbé Vogler's revision of Pergolesi's „Stabat Mater”, „Journal of the American Musicological Society” 1 (30) (1977), s. 43-71. 
Muzycznym uzewnętrznieniem lamentu człowieka nad cierpiącym Chrystusem i Marią oraz pragnienia naśladowania Dziewicy na jej drodze boleści stają się często tzw. motywy westchnieniowe. Zazwyczaj stanowią je opadające interwały sekundowe, lecz w utworze Domenica Scarlattiego dodatkowo tworzą je repetycje krótkich motywów lub pojedynczych tonów. W części Eia Mater wraz ze słowami me sentire vim doloris kompozytor wprowadza powtórzenia dźwięków na tej samej wysokości, uzyskując w ten sposób efekt „zakorzenienia” w jednej płaszczyźnie brzmieniowej i pożądaną intonację litanijną, lamentacyjno-błagalną.

Wizerunek nieskalanej „Dziewicy Dziewic”, łagodnej Matki (strofa 15. sekwencji), ale i charakter kornej, lecz pogodnej prośby najbardziej wyraziście kreuje w swej interpretacji Luigi Boccherini. Kompozytor wprowadza wypowiedź typu aryjnego, śpiewnego (co wiąże się z tradycją włoskiego bel canto), tonację „jasną", durową (B-dur), a sposób kształtowania materiału w partiach instrumentalnych przywodzi na myśl serenadę. Nadmienić można, że w całości dzieło Luigiego Boccheriniego wyróżnia się ekspresją mało dramatyczną, stonowaną. Stąd też utwór określany bywa „przedłużonym lamentem”"14. Być może należałoby przypisać mu również miano semplice e divoto ${ }^{15}$. Sam kompozytor przyznał, że stworzył kompozycję facile (prostą, łatwą), od interpretatora niewymagającą niczego więcej, jak tylko precyzji i prostoty $\mathrm{w}$ wykonaniu ${ }^{16}$.

Ton coraz bardziej żarliwej modlitwy, pełnej płomiennej miłości do Chrystusa i Maryi dominował w końcowych strofach sekwencji. W swojej interpretacji tekstu Fac ut portem Giovanni Battista Pergolesi zastosował kontrast pomiędzy partiami wielogłosowymi a unisonowymi (all'unisono), tok narracji nasycił ugrupowaniami punktowanymi i przerywał pauzami, co dało efekt niezwykłego ładunku emocjonalnego. Arię skon-

14 A. Beaujean, Nota do wydania płytowego (CD) Stabat Mater L. Boccheriniego (wersja I), Sony Music Entertainment Inc. 2003, s. 12.

15 Określenia przejęte za Mieczysławem Tomaszewskim, por. TENżE, Nad pieśniami Karola Szymanowskiego. Cztery studia, Kraków 1998, s. 79.

16 Por. G. Salvetti, Boccherini, w: A. Basso (red.), Dizionario Enciclopedico Universale della Musica e dei Musicisti, Le Biografie, t. 1, Torino 1986, s. 570. 
trastował również z kolejnym duetem, opracowując tekst strofy 18 . w tonie odmiennym - łagodnym, stającym się wyrazem ufności pokładanej w Maryi, pośredniczce. Muzyka nie niesie ze sobą nadmiaru żarliwych uniesień czy też dramatycznego strachu przed „spłonięciem w płomieniach piekła”. Taki rodzaj umuzycznienia wywołał głosy krytyki w stosunku do „arcydzieła muzyki łacińskiej” "17, jakim okrzyknięto już w 1739 roku Stabat Mater twórcy. Uznano bowiem, że ugrupowania synkopowane, szybkie tempo narracji oraz koncertujący typ partii wokalnej nadają mu charakteru nieadekwatnego do tekstu - tanecznego, pogodnego, wręcz świeckiego. Pamiętną stała się polemika pomiędzy obrońcą dawnego stylu muzyki religijnej Giovannim Battistą Martinim a młodszym o jedno pokolenie i wychowanym na kulturze encyklopedycznej Antoniem Eximeno. Pierwszy z nich wytykał Giovanniemu Battiście Pergolesiemu zwrot w stronę opery, przenoszenie cech charakterystycznych dla dzieła teatralnego na grunt utworu sakralnego, a co za tym idzie sprofanizowanie muzyki kościelnej. Drugi występował w roli obrońcy kompozytora, twierdząc, że pierwiastek sakralny i profaniczny są związane ze sobą, a „muzyka nie czyni wyborów pomiędzy tematami [religijnym a świeckim], jedynie porusza afekty; jeśli tematy odwołują się do sakralnych, muzyka jest sakralną; jeśli dotyczą aspektów świeckich, muzyka jest świecką ${ }^{18}$. W związku z tym Antonio Eximeno widział w Stabat Mater Giovanniego Battisty Pergolesiego „nieśmiertelny przykład” muzyki kościelnej.

Finały dzieł (jako conclusio) przynoszą wspomnienie śmierci - Quando corpus, ale wskazują też na perspektywę życia wiecznego, ostateczny cel i sens - paradisi Gloria. Idea chiaro-scuro znajduje w tym miejscu swój najpełniejszy wydźwięk w postaci kontrastowania różnorakich jakości muzycznych (wolno - szybko, homofonia - polifonia itp.). Fascynujące operowanie czasem i przestrzenią, narracja statyczna („trwanie”), zatopienie się w kontemplacji wyróżniają opracowanie Quando corpus u Domenica Scarlattiego, Agostina Steffaniego i Giovanniego Battisty

17 Słowa te odnotował Charles de Brosses podczas swojej podróży po Italii.

18 G. Stefani, Padre Martini e l'Eximeno: bilancio di una celebre polemica sulla musica di chiesa, „Nuova Rivista Musicale Italiana” 3 (1970), s. 479. 
Pergolesiego. Kompozytorzy stosują ten sam rodzaj zwolnionego ruchu melodyczno-rytmicznego, podobne rejestry lub stopniowe ich rozszerzanie. Tak skonstruowany przebieg muzyczny może prowadzić do szczególnego przeżycia estetyczno-numinotycznego, o którym pisał Władysław Stróżewski, a wraz z tym - doświadczenia sacrum w sztuce ${ }^{19}$.

\section{Conclusio}

W latach nieodległych, zajmując się problematyką funkcji sztuki religijnej, ks. Tadeusz Dzidek podkreślał, iż „wyprowadza [ona] ku transcendencji - nieskończoności, która jest tajemnicą"20. Myśli te wpisują się w przywoływaną już refleksję św. Jana Pawła II o sztuce. Jak wskazywał papież: „Kościół zawsze odwoływał się do zdolności twórczych [artystów], aby wyjaśnić ewangeliczne orędzie i ukazywać jego konkretne zastosowania w życiu chrześcijańskiej wspólnoty" ${ }^{21}$. Spoglądając na XVIII-wieczne kompozycje Stabat Mater z perspektywy ich funkcji $\mathrm{w}$ teologii, ale i w przestrzeni kultury ${ }^{22}$, bez wątpienia można im przypisać kilka znaczących:

- informacyjną i kerygmatyczną, gdyż poprzez interpretacje słowno-muzyczne zostaje wydobyte i uwypuklone znaczenie nowotestamentowych opowieści o męce Pańskiej;

- fatyczną, bowiem muzyka ma zjednoczyć wyznawców, „nastroič" na wspólny religijny ton;

- oraz ekspresywną - w Stabat Mater akcent pada na siłę wyrazu, współodczuwanie przez człowieka czysto ludzkiej boleści Matki na Golgocie i cierpienia Jej Syna, ale i intensywną modlitwę wierzącego o umocnienie przez Krzyż.

19 Zob. W. Stróżewski, O możliwości sacrum w sztuce, w: N. Cieślińska (oprac.), Sacrum i sztuka, Kraków 1989, s. 36.

20 T. Dzidek, Funkcje sztuki w teologii, Kraków 2013, s. 35.

21 Jan Pawee II, List..., dz. cyt., s. 108.

22 Por. M. JabŁoński, Muzyka jako znak, Poznań 1999, s. 36; M. Tomaszewski, O muzyce polskiej w perspektywie intertekstualnej. Studia i szkice, Kraków 2005, s. 12-13. 
Wiesław Lisecki, analizując Stabat Mater Karola Szymanowskiego, stwierdził, iż duchowość franciszkańska „bardziej koncentruje się na przeżywaniu Prawdy, mniej - na racjonalnym jej dowodzeniu", stąd też uznał, że w omawianej sekwencji więcej miejsca zajmuje „przeżycie niż teologia"23. Wypowiedź ta wydaje się kluczowa, jeśli odnieść ją do analizowanych kompozycji. Adelmo Damerini, charakteryzując włoską muzykę religijną XVIII wieku, podkreślał, że dla Italii był to czas, kiedy „dusza ludzka nie potrafiła zatopić się w kontemplacji bezosobowej, abstrakcji mistycznej, lecz czuła potrzebę wyrażenia w uczuciowości religijnej namiętności ziemskich"24. Z pewnością potwierdzeniem tych słów są włoskie umuzycznienia Stabat Mater, w których na plan pierwszy wysuwa się nie tyle przesłanie teologiczne, co afektywne (emocjonalne).

W czasach współczesnych Stabat Mater wielkich twórców - przede wszystkim Giovanniego Battisty Pergolesiego, ale i Antonia Vivaldiego, obu Scarlattich czy Luigiego Boccheriniego - rozbrzmiewają głównie jako dzieła koncertowe we wnętrzach kościelnych lub świeckich. Żywotność tych interpretacji 300 lat od ich powstania świadczy niewątpliwie o kompozytorskim kunszcie utworów oraz o ich znaczeniu nie tylko dla muzyki XVIII wieku, ale i dla dzisiejszej kultury i wiary. Dzieła dawnych mistrzów koncentrujące się wokół istoty cierpienia Maryi, Niepokalanej i bezgrzesznej - nawiązując do słów Danuty Mastalskiej - z pewnością i obecnie „mogą być wyzwaniem dla naszych przemyślen’” ${ }^{25}$.

\section{Bibliografia}

Beaujean A., Nota do wydania płytowego (CD) Stabat Mater L. Boccheriniego (wersja I), Sony Music Entertainment Inc. 2003, s. 10-13.

Blume J., Geschichte der mehrstimmigen Stabat-mater-Vertonungen, MünchenSalzburg 1992.

${ }^{23}$ W. LISECKI, „Stabat Mater”..., dz. cyt., s. 112.

24 A. DAmerini, Lo spirito della musica religiosa nel settecento italiano, „La Rassegna Musicale" 3 (1934), s. 189.

25 D. Mastalska, Stabat Mater Dolorosa. Uwagi o znaczeniu cierpień Maryi pod krzyżem w dziele odkupienia, „Salvatoris Mater” 3 (2001), s. 47. 
Caldwell J., Boyd M., Stabat Mater dolorosa w: S. Sadie, J. Tyrrell (red.), The New Grove Dictionary of Music and Musicians, second ed., t. 24, London 2001, s. 234-236.

Damerini A., Lo spirito della musica religiosa nel settecento italiano, „La Rassegna Musicale" 3 (1934), s. 186-197.

Dzidek T., Funkcje sztuki w teologii, Kraków 2013.

Faravelli D., Stabat Mater: poesia e musica, „Rivista Internazionale di Musica Sacra" 1 (1983), s. 9-43.

Grave F. K., Abbé Vogler's revision of Pergolesi's „Stabat Mater”, „Journal of the American Musicological Society" 1 (30) (1977), s. 43-71.

Harnoncourt N., Muzyka mową dźwięków, tłum. M. Czajka, Warszawa 1995.

Henry H. T., Masiclat P.-D., Stabat Mater dolorosa, w: The Catholic Encyclopedia, Online Edition 2003, https://www.newadvent.org/cathen/ (odczyt z dn. 15.04.2021 r.).

Jabłoński M., Muzyka jako znak, Poznań 1999.

Jan Paweł II, List do artystów, Rzym 1999.

Jasiński T., „Imaginatio crucis” w muzyce baroku, „Zeszyty Naukowe” [Akademia Muzyczna im. I. J. Paderewskiego w Poznaniu] 6 (1994), s. 65-82.

Lisecki W., „Stabat Mater” Karola Szymanowskiego jako muzyczna interpretacja przesłania sekwencji, „Zeszyty Naukowe” [Akademia Muzyczna im. F. Nowowiejskiego w Bydgoszczy] 5 (1993), s. 111-117.

Mastalska D., Stabat Mater Dolorosa. Uwagi o znaczeniu cierpień Maryi pod krzyżem $w$ dziele odkupienia, „Salvatoris Mater” 3 (2001), s. 47-87.

Mearns J., Stabat Mater, w: J. Julian (red.), A Dictionary of Hymnology, London 1907, s. 1081-1083.

Mianowski J., Afekt w operach Mozarta i Rossiniego, Poznań 2004.

Nadolski B., Liturgika, t. 2: Liturgia i czas, Poznań 2013.

Nohl P.-G., Das „Stabat Mater”, „Musik und Kirche” 67 (1997), s. 97-106.

Salvetti G., Boccherini, w: A. Basso (red.), Dizionario Enciclopedico Universale della Musica e dei Musicisti, Le Biografie, t. 1, Torino 1986, s. 570. 
Schlagen K.-H., Marx-Weber M., Stabat Mater, w: L. Finscher (hrsg. von), Die Musik in Geschichte und Gegenwart, Sachteil, t. 8, Kassel-Stuttgart 1998, s. $1708-1721$.

Sharp A. T., A Descriptive Catalog of Selected, Published Eighteenth- through Twentieth-Century Stabat Mater Settings for Mixed Voices with a Discussion of the History of the Text, Ph.D. Thesis, University of Iowa 1978.

Stefani G., Padre Martini e l'Eximeno: bilancio di una celebre polemica sulla musica di chiesa, „Nuova Rivista Musicale Italiana” 3 (1970), s. 463-481.

Stróżewski W., O możliwości sacrum w sztuce, w: N. Cieślińska (oprac.), Sacrum i sztuka, Kraków 1989, s. 23-38.

Szwarc U., „Twoją duszę miecz przeniknie” (Łk 2,35). Cierpienie Maryi w świetle starotestamentowego przepowiadania, „Salvatoris Mater” 3 (2001), s. 11-25.

Tomaszewski M., Nad pieśniami Karola Szymanowskiego. Cztery studia, Kraków 1998.

Tomaszewski M., O muzyce polskiej w perspektywie intertekstualnej. Studia i szkice, Kraków 2005.

Dr hab. Renata Borowiecka - teoretyk muzyki, absolwentka Akademii Muzycznej w Krakowie. W macierzystej uczelni pracuje od 1996 roku, obecnie na stanowisku adiunkta (Katedra Teorii i Interpretacji Dzieła Muzycznego). Przez 10 lat współpracowała z Filharmonią im. K. Szymanowskiego w Krakowie jako prelegent audycji muzycznych dla dzieci i młodzieży, a od 2009 roku jest również nauczycielem przedmiotów ogólnomuzycznych w Szkole Muzycznej I i II st. im. B. Rutkowskiego w Krakowie. Członek Sekcji Muzykologów Związku Kompozytorów Polskich oraz Polskiego Towarzystwa Analizy Muzycznej. W pracy naukowej początkowo skoncentrowana na włoskiej muzyce dawnej. Przyznane w 2002 roku stypendium rządu włoskiego na kwerendę naukową, prowadzoną na Università degli Studi di Firenze, zaowocowało dysertacją doktorską (2007) Sekwencja „Stabat Mater” w twórczości kompozytorów włoskich XVIII wieku. Od słowa do muzycznej interpretacji (w 2010 roku praca otrzymała wyróżnienie na konkursie ZKP o Nagrodę im. ks. prof. H. Feichta). Po doktoracie w kręgu jej zainteresowań pozostaje polska współczesna muzyka 
religijna. Zwieńczenie wieloletnich badań stanowi obszerna monografia Twórczość religijna Pawła Łukaszewskiego. Muzyka jako wyraz zmysłu wiary artysty (2019). Jej dorobek naukowy obejmuje także artykuły i hasła encyklopedyczne wydane $\mathrm{w}$ Polsce i za granicą oraz wystąpienia $\mathrm{z}$ referatami podczas krajowych i międzynarodowych konferencji naukowych. Dziedziny zainteresowań: muzyka religijna, muzyka dawna kręgu włoskiego, twórczość Pawła Łukaszewskiego. 